Article

\title{
Treatment of Flue Gas Desulfurization Wastewater by an Integrated Membrane-Based Process for Approaching Zero Liquid Discharge
}

\author{
Carmela Conidi ${ }^{1}$, Francesca Macedonio ${ }^{1,2, *(\mathbb{D})}$, Aamer Ali ${ }^{1}$, Alfredo Cassano ${ }^{1, *(\mathbb{D} \text {, }}$ \\ Alessandra Criscuoli ${ }^{1}$, Pietro Argurio ${ }^{2}$ (1) and Enrico Drioli ${ }^{1}$ (1) \\ 1 Institute on Membrane Technology, ITM-CNR, c/o University of Calabria, via P. Bucci, 17/C, \\ I-87036 Rende (CS), Italy; c.conidi@itm.cnr.it (C.C.); amir_hmmad@hotmail.com (A.A.); \\ a.criscuoli@itm.cnr.it (A.C.); e.drioli@itm.cnr.it (E.D.) \\ 2 Department of Environmental and Chemical Engineering, University of Calabria, Via P. Bucci, 44/A, \\ I-87036 Rende (CS), Italy; pietro.argurio@unical.it \\ * Correspondence: francesca.macedonio@unical.it (F.M.); a.cassano@itm.cnr.it (A.C.); Tel.: +39-0984-492-012 \\ (F.M.); +39-0984-492067(A.C.)
}

Received: 25 October 2018; Accepted: 22 November 2018; Published: 26 November 2018

check for updates

\begin{abstract}
An integrated membrane process for the treatment of wastewaters from a flue gas desulfurization (FGD) plant was implemented on a laboratory scale to reduce their salt content and to produce a water stream to be recycled in the power industry. The process is based on a preliminary pretreatment of FGD wastewaters, which includes chemical softening and ultrafiltration (UF) to remove $\mathrm{Ca}^{2+}$ and $\mathrm{Mg}^{2+}$ ions as well as organic compounds. The pretreated wastewaters were submitted to a reverse osmosis ( $\mathrm{RO})$ step to separate salts from water. The $\mathrm{RO}$ retentate was finally submitted to a membrane distillation (MD) step to extract more water, thus increasing the total water recovery factor while producing a high-purity permeate stream. The performance of $\mathrm{RO}$ and MD membranes was evaluated by calculating salts rejection, permeate flux, fouling index, and water recovery. The investigated integrated system allowed a total recovery factor of about $94 \%$ to be reached, with a consequent reduction of the volume of FGD wastewater to be disposed, and an MD permeate stream with an electrical conductivity of $80 \mu \mathrm{S} / \mathrm{cm}$, able to be reused in the power plant, with a saving in fresh water demand.
\end{abstract}

Keywords: FGD wastewater; integrated membrane-based process; zero liquid-discharge; sustainability

\section{Introduction}

Much research is today focusing on minimizing the scarcity of potable water and the impact of air, water, and solid waste pollutants. Among them, to improve the control of $\mathrm{SO}_{2}$ emissions, various flue gas desulfurization (FGD) technologies have been developed in the last decades.

Flue gas desulfurization processes are primarily used to remove $\mathrm{SO}_{2}$ from exhaust flue gases of fossil fuel thermoelectric power plants. In these plants, $\mathrm{SO}_{2}$ is produced during the combustion of coal and oil, and can be further converted (about $1 \%$ ) into sulfur trioxide $\left(\mathrm{SO}_{3}\right)$ if high contents of oxygen are present [1]. The commonly used FGD technologies are: Wet and spray-dry scrubbing (using a slurry of alkaline sorbents, like limestone or lime, or seawater); the wet sulfuric acid process (recovering sulfur as sulfuric acid); and dry sorbent injection systems.

Depending on the coal source, used technology, and operating conditions, FGD processes can give origin to various streams, with a different and complex composition. Chloride, sulfate, nitrate, calcium, magnesium as well as various heavy metals and dissolved silica and borate are 
often present. Moreover, FGD wastewater may have a content of total dissolved solids (TDS) as high as $50,000 \mathrm{mg} / \mathrm{L}$ [2].

The treatment of FGD wastewater represents one big issue in the water industry [2,3]. One possibility is to use biotechnological treatments, which, however, lead to the production of $\mathrm{H}_{2} \mathrm{~S}$ [4].

Another option consists in applying chemical precipitation-based strategies for heavy metal removal, which use alkaline compounds, such as $\mathrm{Ca}(\mathrm{OH})_{2}$ (hydrated lime), $\mathrm{NaOH}$ (caustic soda), or $\mathrm{Na}_{2} \mathrm{CO}_{3}$ (soda ash), leading to the production of insoluble hydroxides. This approach is limited by the production of huge quantities of heavy metal hydroxide and calcium sulfate sludge that have to be disposed in a regulated hazardous waste facility.

The use of zero-valent iron ( $\mathrm{ZVI}$ or $\mathrm{Fe} 0$ ) as reactive media for treating heavy metal contaminated groundwater has also been investigated in the last years [5-8]. The addition of iron promotes the removal of dissolved heavy metals by several mechanisms, including cementation, precipitation of metal hydroxides, and adsorption [9]. This approach has also been evaluated for the removal of selenium [10,11], mercury, and other heavy metals [12] from FGD wastewaters. In particular, continuous-flow field tests conducted on a fluidized bed system consistently reduced $\mathrm{Hg}$ from ca. 50 to $<0.005 \mu \mathrm{g} / \mathrm{L}$ and Se (mostly as selenate) from ca. $3000 \mathrm{to}<7 \mu \mathrm{g} / \mathrm{L}$. Most of the heavy metals were all reduced to near- or sub-ppb levels [12]. However, the potential of ZVI as a reagent for remediating contaminated FGD wastewaters is limited by the rapid loss of ZVI reactivity upon the formation of iron corrosion products as a passive coating on the ZVI grains [13].

In recent years, the potential of membrane operations, like microfiltration (MF), ultrafiltration (UF), nanofiltration (NF), and reverse osmosis (RO), for treatment of different wastewaters has been investigated. The attraction of membrane operation was, among others, due to their capability of removing almost all pollutants with a reduced addition of chemicals (only the amount necessary for membrane pre-treatment and cleaning).

Apart from chemical and biotechnological processes, membrane operations can be a viable approach for the remediation of FGD wastewaters, although few studies have been reported until now on this subject. The performance of a coprecipitation method of heavy metal hydroxides and sulphides followed by crossflow microfiltration (CMF) in the treatment of wastewater from a FGD plant was analyzed by Enoch et al. [14]. The removal efficiency of both hydrophilic and hydrophobic membranes was satisfactory, except for Cd removal.

Liu et al. [15] also used MF membranes, with and without an initial chemical precipitation, for the removal of $\mathrm{Hg}^{2+}$ from FGD wastewater, demonstrating the feasibility of the process.

An integrated membrane system, constituted of a sedimentation tank for particles sedimentation, UF, NF, and RO, was utilized by Yin et al. [16] for the treatment of the desulfurization wastewater. In particular, the sedimentation step revealed to be fundamental to improve UF flux and permeate quality. As a matter of fact, without pre-sedimentation, a lower steady flux of $200 \mathrm{~L} / \mathrm{m}^{2} \mathrm{~h}$ was reached, compared to about $500 \mathrm{~L} / \mathrm{m}^{2} \mathrm{~h}$ achieved in the UF process with pre-sedimentation, at a transmembrane pressure (TMP) of $0.15 \mathrm{MPa}$, temperature of $40{ }^{\circ} \mathrm{C}$, and cross-flow velocity (CFV) of $4 \mathrm{~m} / \mathrm{s}$. UF retained $99.9 \%$ of the initial suspended sulfur (SS) while salt compounds passed through the UF membrane and were recovered in the permeate. Therefore, UF ceramic membranes were considered for removing SS, generating a permeate stream able to be treated by the NF unit. The NF unit separated bivalent ammonium salts from monovalent ammonium salts and the obtained NF permeate was sent to RO to separate monovalent salts from water, and to recover ammonium thiocyanate. The analyzed integrated membrane process (UF/NF/RO) was able to reduce environmental loads and to make possible the recovery of various valuable substances (such as, sulfur and $\mathrm{NH}_{4} \mathrm{SCN}$ ) and the water reuse.

Being a pressure driven membrane operation that is well consolidated also at the industrial level, $\mathrm{RO}$ has the great advantage of producing high quality water (rejection factor higher than $99 \%$ for monovalent and bivalent ions in the feed) at a relatively low energy consumption ( 3 and $4 \mathrm{kWh} / \mathrm{m}^{3}$ are typical values at around a 50\% recovery factor). The main RO limitation is the high feed pressure 
required for overcoming the feed side osmotic pressure, which usually ranges from 55 to 68 bar for a salinity of about $35 \mathrm{~g} / \mathrm{L}$, and that is around 15 bar for salinity between 0.5 and $30 \mathrm{~g} / \mathrm{L}$ [17]. Being a thermally driven membrane separation technology, in membrane distillation (MD), operating pressures are generally on the order of a few hundred $\mathrm{kPa}$. Moreover, its performance is less affected by concentration polarization than pressure driven membrane operations, allowing the treatment of higher salinity water and leading to a higher recovery factor, then reducing the environmental impact of the produced brine and with the potential to achieve near zero discharge. In fact, various studies proved that MD could accomplish nearly complete salt rejection and high water reclamation in the treatment of high-salinity wastewater [18-21], as is the case of FGD wastewater produced by seawater scrubbing. Moreover, MD has the additional advantage of a relatively low operating temperature, with the possibility to utilize either waste heat or renewable energy resources (such as geothermal or solar energy) or the low-grade heat available in power plants [22-24].

Jia and Wang [25] recently investigated an integrated process for the treatment of flue gas desulfurization wastewater based on chemical softening followed by NF and MD working on the NF permeate. They found that the chemical softening and the NF pretreatment could significantly decrease membrane scaling in MD. Moreover, over $99.99 \%$ salt rejection and over $92 \%$ of water reclamation were achieved. The MD configuration used by authors was the vacuum membrane distillation (VMD) because of its high flux. Nevertheless, this configuration needs the use of a vacuum pump and of an external condenser for the permeate recovery.

In a previous work, we evaluated the performance of two commercial RO spiral-wound membranes (SWC-2540 and ESPA-2540 both from Hydranautics) for the removal of salt compounds from softened and ultrafiltered FGD wastewaters [26]. The SWC membrane was more effective than the ESPA membrane in terms of ions rejection, fouling index, and cleaning efficiency, and a permeate conductivity lower than $2 \mathrm{mS} / \mathrm{cm}$ was obtained. Based on the positive results achieved, in the current study, we investigated the possibility to treat the RO brine produced by a SWC-2540 RO membrane in an MD unit, with the aim of producing higher purity water as MD permeate, while reducing the brine volume to be disposed. As in the previous study [26], FGD wastewaters were submitted to a pre-treatment step (softening and UF) aimed at reducing $\mathrm{Ca}^{2+}$ and $\mathrm{Mg}^{2+}$ content, as well as the organic content, to minimize scaling. The UF permeate was then processed by the SWC-2540 RO membrane and its brine was finally submitted to an MD step (Figure 1). Direct Contact Membrane Distillation (DCMD) was chosen because, among the MD configurations, it is the simplest to operate, requiring the least equipment.

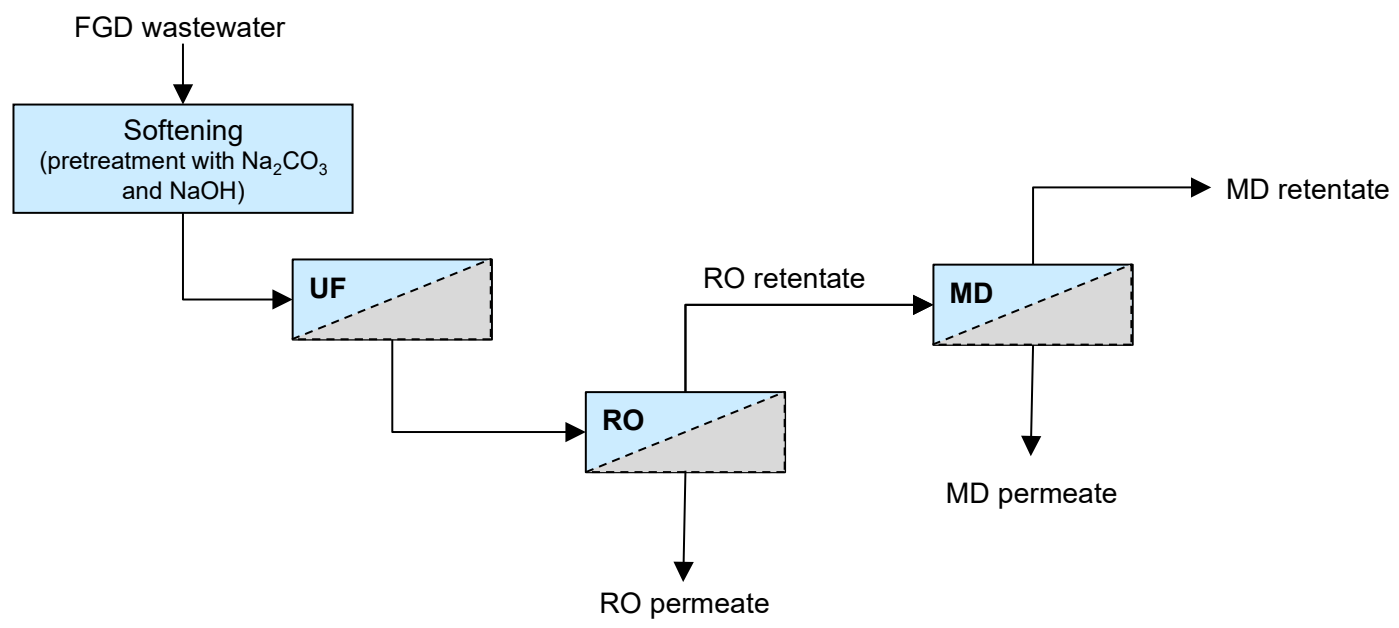

Figure 1. Scheme of the integrated membrane system investigated. 


\section{Materials and Methods}

\subsection{Pretreatment of FGD Wastewaters}

FGD wastewaters were collected from the thermal power plant of Industrial Enel Research (Brindisi, Italy). The whole pretreatment process consisted of softening agents' addition followed by UF.

FGD wastewaters were softened with $\mathrm{Na}_{2} \mathrm{CO}_{3} \cdot \mathrm{H}_{2} \mathrm{O}\left(\mathrm{Na}_{2} \mathrm{CO}_{3} \cdot \mathrm{H}_{2} \mathrm{O} / \mathrm{Ca}\right.$ molar ratio 2.6/1) and $\mathrm{NaOH}(\mathrm{NaOH} / \mathrm{Mg}$ molar ratio 1.5/1); the solutions were incubated for $1 \mathrm{~h}$ at room temperature and then pre-filtered with filter paper (pore size of about 10-20 $\mu \mathrm{m}$ ) before acidification with $\mathrm{H}_{2} \mathrm{SO}_{4}$ up to $\mathrm{pH}$ 6.5. Afterwards, the FGD wastewaters were treated with an antiscalant (Carboxyline CM supplied by Aquastill B.V., Sittard, The Netherlands) at the recommended concentration $(8 \mathrm{mg} / \mathrm{L})$ in order to prevent the precipitation of low soluble salts.

Cross-flow UF was performed by using a hollow fiber polyethersulphone (PES) membrane module (FUS 5082, Microdyn Nadir, Wiesbaden, Germany), having a nominal molecular weight cut-off (MWCO) of $500 \mathrm{kDa}$ and an effective membrane area of $0.25 \mathrm{~m}^{2}$. A feed-and-bleed configuration (in order to work at constant feed volume, during the experiments feed was added in the feed tank in the same amount of the produced permeate) was operated until a recovery factor (RF) of $98 \%$ was obtained at the following experimental conditions: TMP of $0.45 \mathrm{bar}$, axial feed flowrate $\left(\mathrm{Q}_{\mathrm{f}}\right)$ of $560 \mathrm{~L} / \mathrm{h}$, and temperature $(\mathrm{T})$ of $25 \pm 1{ }^{\circ} \mathrm{C}$. In the selected operating conditions, average permeate fluxes in the range of $460-500 \mathrm{~kg} / \mathrm{m}^{2} \mathrm{~h}$ were registered.

After the treatment with FGD wastewater, the UF membrane module was rinsed with distilled water for $30 \mathrm{~min}$ and then cleaned by recycling an acid detergent (Ultraclean WO, Henkel Chemicals Ltd., Dusseldorf) at a concentration of $0.1 \%$ (w/w) (pH 4) for 60 min at $40{ }^{\circ} \mathrm{C}$. After, the membrane module was rinsed with distilled water for $20 \mathrm{~min}$. The cleaning-in-place procedure allowed more than $98 \%$ of the initial permeability of the UF membrane to be recovered.

\subsection{RO and MD: Experimental Set-Up and Membranes}

RO experiments were carried out using the laboratory set-up of Matrix Desalination Inc. (Florida, USA), which incorporated a stainless steel housing able to accommodate a $2.4 \times 21$ in. spiral-wound membrane module with an effective membrane surface area of $2.34 \mathrm{~m}^{2}$ (main properties are listed in Table 1). The equipment consists of a feed tank with a capacity of $20 \mathrm{~L}$, a high-pressure pump, a back-pressure valve, two pressure gauges, a permeate control valve, and a coiling cool fed with tap water used to maintain the control the feed temperature.

Table 1. Characteristics of the reverse osmosis (RO) membrane module.

\begin{tabular}{ll}
\hline Membrane Type & SWC-2540 \\
Membrane Material & Composite polyamide \\
Configuration & Spiral-wound \\
Salt Rejection (\%) & 99.4 (minimum 99.0) \\
pH Operating Range & $2-11$ \\
Max. Operating Temperature $\left({ }^{\circ} \mathbf{C}\right)$ & 45 \\
Max. Operating Pressure $(\mathbf{b a r})$ & 69 \\
Membrane Surface Area $\left(\mathbf{m}^{2}\right)$ & 2.34 \\
Water Permeability $\left(\mathbf{k g} / \mathbf{m}^{2} \mathbf{h b a r}\right)$ & $1.77^{\mathrm{a}}$ \\
Zeta Potential $(\mathbf{m V})$ & -21.2 at $\mathrm{pH} 7^{\mathrm{b}}$ \\
Contact Angle & $96.05 \pm 4.35^{\mathrm{c}}$ \\
\hline \multicolumn{1}{c}{${ }^{\mathrm{a}}$ our data; ${ }^{\mathrm{b}}$ data from Li et al. $[27]^{\mathrm{c}}$ data from Lee et al. [28]. }
\end{tabular}

The pretreated FGD wastewaters were treated in a spiral-wound RO membrane module (SWC-2540) supplied by Hydranautics Corporation (Oceanside, CA, USA), whose properties are summarized in Table 1. Experiments were performed according to a feed-and-bleed configuration in selected operating conditions (TMP, 36 bar; $\mathrm{Q}_{\mathrm{f}}, 204 \mathrm{~L} / \mathrm{h} ; \mathrm{T}, 26.5^{\circ} \mathrm{C}$ ) up to an $\mathrm{RF}$ of $60 \%$. 
The permeate flux was determined by weighing the amount of permeate collected vs. time and using the following equation:

$$
J_{p}=\frac{m_{p}}{A \cdot t}
$$

where $J_{p}$ is the permeate flux $\left(\mathrm{kg} / \mathrm{m}^{2} \mathrm{~h}\right), m_{p}$ the permeate weight $(\mathrm{kg})$ at time, $t(\mathrm{~h})$, and $A$ is the membrane surface area $\left(\mathrm{m}^{2}\right)$.

The water permeability $\left(W_{p}\right)$ of the membrane was obtained as the slope of the straight line resulting from plotting the water flux at $25^{\circ} \mathrm{C}$ versus the applied TMP.

After each experiment, the $\mathrm{RO}$ membrane was rinsed with water at $30^{\circ} \mathrm{C}$ and then cleaned with an acid solution (Ultraclean $\mathrm{WO} 0.05 \%, \mathrm{pH} 4$ ) at $40{ }^{\circ} \mathrm{C}$, for $60 \mathrm{~min}$. Then, the membrane was rinsed with distilled water for $20 \mathrm{~min}$ and the water permeability was remeasured.

The fouling index of the $\mathrm{RO}$ membrane $\left(F I_{R O}\right)$ was calculated by the following equation:

$$
F I_{R O}=\left(1-\frac{W_{p 1}}{W_{p 0}}\right) \cdot 100
$$

where $W_{p 0}$ and $W_{p 1}$ are the water permeability measured before and after the FGD wastewater treatment.

The cleaning efficiency was evaluated by using the water flux recovery method, according to the following equation:

$$
C E=\left(\frac{W_{p 3}}{W_{p 0}}\right) \cdot 100
$$

where $W_{p 3}$ is the water permeability measured after the chemical cleaning.

Membrane distillation was performed in a direct contact configuration (DCMD). In the lab plant, the $\mathrm{MD}$ feed (i.e., $\mathrm{RO}$ retentate) and the MD permeate streams (i.e., demineralized water) converge in the counter-current mode towards the membrane module containing the flat oleophobic membrane supplied by Aquastill. The main properties of the used membrane are summarized in Table 2.

Table 2. Characteristics of the oleophobic membrane used in membrane distillation (MD).

\begin{tabular}{ll}
\hline Membrane Material & Polyethyelene-oleophobic (PE-O) \\
Configuration & Flat sheet \\
Active Module Length & $50 \mathrm{~cm}$ \\
Membrane Area & $0.05 \mathrm{~m}^{2}$ \\
Mean Pore Size & $0.3 \mu \mathrm{m}$ \\
Porosity & $80 \%$ \\
Membrane Thickness & $76 \mu \mathrm{m}$ \\
Liquid Entry Pressure (LEP) & $>4 \mathrm{bar}$ \\
Contact Angle & $>118^{\circ}$ \\
\hline
\end{tabular}

The driving force in DCMD is a vapour pressure difference across the membrane, which is imposed by a temperature difference across the membrane. Therefore, the retentate line was heated by an ISCO GTR 2000 heater (Isco srl, Fizzonasco di Pieve Emanuele (MI), Italy) whilst the permeate line was cooled by a RTE 17 NESLAB refrigerated bath chiller circulator (Thermo Electron Corporation, Newington, CT, USA). The retentate solution and distillate coming out from the module were returned back to the feed tank and permeate tank, respectively, both working at atmospheric pressure. Magnetic drive gear pumps (Iwaki Co., Ltd., Tokyo, Japan) were used to recirculate the streams. The plant was also equipped with flow meters, thermocouples, manometers, and a conductivity meter.

The trans-membrane flux was calculated by evaluating weight variations in the distillate tank by a Gibertini EU-C LCD balance (Gibertini Elettronica, Novate Milanese (MI), Italy). After each experiment, the MD membrane was rinsed with water. The fouling index of the MD membrane $\left(F I_{M D}\right)$ was calculated by:

$$
F I_{M D}=\left(1-\frac{J_{w 1}}{J_{w 0}}\right) \cdot 100
$$


where $J_{w 0}$ and $J_{w 1}$ are the MD trans-membrane flux before and after RO retentate treatment, respectively, when distilled water is used as the MD feed and the membrane process is carried out at $48^{\circ} \mathrm{C}$.

On the basis of previous MD experiments directly performed on FGD wastewaters [29], experimental runs were carried out at the operative conditions reported in Table 3.

Table 3. MD operative conditions.

\begin{tabular}{ll}
\hline MD Feed Solution & RO brine \\
$\mathbf{T}_{\text {Feed, in }}{ }^{\circ} \mathbf{C}$ & $69 \pm 0.1$ \\
$\mathbf{T}_{\text {Permeate, in },}{ }^{\circ} \mathbf{C}$ & $28 \pm 0.3$ \\
Feed Flow Rate, 1/min & 0.5 \\
Permeate Flow Rate, $1 /$ min & 0.4 \\
\hline
\end{tabular}

\subsection{Analytical Measurements}

The different samples collected from the investigated processes were analyzed for electrical conductivity (EC), total dissolved solids (TDS), $\mathrm{Ca}^{2+}, \mathrm{Mg}^{2+}, \mathrm{Na}^{+}, \mathrm{TOC}$, and $\mathrm{pH}$.

The removal efficiency for each component was expressed in terms of rejection $(\mathrm{R})$ according to the following equation:

$$
R=1-\left(\frac{C_{p}}{C_{f}}\right) \cdot 100
$$

where $C_{f}$ and $C_{p}$ are the concentrations of a specific component in the feed and permeate, respectively.

EC and TDS were measured using a digital conductivity meter (HI 2300 Microprocessor Conductivity, Hanna Instruments, Woonsocket, RI, USA).

$\mathrm{Ca}^{2+}, \mathrm{Mg}^{2+}$, and $\mathrm{Na}^{+}$concentrations were determined by using a high-resolution continuum source atomic absorption spectrometer (HR-CSAAS, ContrAA700, Analytik Jena AG, Jena, Germany), with a high intensity Xe short arc lamp as a continuum source. Samples and standards were appropriately diluted (300 times for $\mathrm{Mg}$ and $\mathrm{Ca}, 3000$ times for $\mathrm{Na}$ ). Subsequently, they were acidified with $1 \% \mathrm{HCl}$ and the absorbance measurements were performed using the spectral lines at $422.67 \mathrm{~nm}$, $588.99 \mathrm{~nm}$, and $285.21 \mathrm{~nm}$ for $\mathrm{Ca}^{2+}, \mathrm{Na}^{+}$, and $\mathrm{Mg}^{2+}$, respectively.

pH was measured by an Orion Expandable ion analyzer EA 920 pH meter (Allometrics, Inc., Baton Rouge, LA, USA) with automatic temperature compensation.

Total organic carbon (TOC) was analyzed by a TOC analyzer (TOC-V CSN, Shimadzu, Kyoto, Japan).

\section{Results and Discussion}

\subsection{Pretreatment of FGD Wastewaters}

The chemical composition of FGD wastewater before and after the pre-treatment step is reported in Table 4. Raw waters were characterized by a lower content of $\mathrm{Ca}^{2+}$ and $\mathrm{Mg}^{2+}$ when compared to typical FGD wastewaters sampled by United States Environmental Protection Agency (USEPA) in several US thermal plants $\left(\mathrm{Ca}^{2+}\right.$ in the range of $2000-5400 \mathrm{ppm}$ and $\mathrm{Mg}^{2+}$ in the range of 1000-4200 ppm, respectively) [3]. Indeed, the concentration of $\mathrm{Ca}^{2+}$ and $\mathrm{Mg}^{2+}$ before the pre-treatment was approximately $384.4 \pm 4.8 \mathrm{ppm}$ and $289.9 \pm 2.6 \mathrm{ppm}$, respectively. On the other hand, the average content of $\mathrm{Na}^{+}$in the raw water was significantly higher $(7.28 \pm 0.6 \mathrm{~g} / \mathrm{L})$ than that found in typical wastewaters sampled by USEPA (50-2000 $\mathrm{mg} / \mathrm{L})$ [3]. These differences can be attributed to several aspects, which contribute to the pollutant concentrations of FGD wastewaters, including the coal type, the sorbent used, the materials of construction in the FGD system, and the FGD system operation. The addition of sodium carbonate and sodium hydroxide in the conditions previously optimized [26] permitted the content of $\mathrm{Ca}^{2+}$ and $\mathrm{Mg}^{2+}$ of raw wastewaters to be reduced, with a removal efficiency of $90.0 \%$ and $78.8 \%$, respectively. A lower removal efficiency was measured for $\mathrm{Na}+(3.84 \%)$. The chemical pre-treatment allowed the achievement of a $7.4 \%$ removal of TDS (from $16.9 \pm 0.6 \mathrm{~g} / \mathrm{L}$ to $15.7 \pm 0.8 \mathrm{~g} / \mathrm{L}$ ); 
a further removal was reached after the UF treatment, with a final overall value of $13.49 \%$. The UF process slightly changed the concentrations of the analysed compounds if compared with the chemical pre-treated FGD wastewater, as it could be expected from the MWCO of the used UF membrane. Nevertheless, the UF step removed more than $60 \%$ of TOC. This rejection value can be explained assuming the presence of not totally dissolved organic solids forming micro-droplets with a size in the range of the MWCO of the UF membrane.

Table 4. Chemical composition of flue gas desulfurization (FGD) wastewater before and after pre-treatment.

\begin{tabular}{ccccc}
\hline \multirow{2}{*}{ Parameter } & \multicolumn{3}{c}{ Sample } & $\begin{array}{c}\text { Overall } \\
\text { Removal (\%) }\end{array}$ \\
\cline { 2 - 4 } & Raw Water & After Softening & After UF & \\
\hline $\mathrm{Ca}^{2+}(\mathrm{ppm})$ & $384.4 \pm 4.8$ & $39.16 \pm 2.1$ & $38.13 \pm 2.1$ & 90.00 \\
$\mathrm{Mg}^{2+}(\mathrm{ppm})$ & $289.9 \pm 2.6$ & $62.5 \pm 0.5$ & $62.4 \pm 0.1$ & 78.84 \\
$\mathrm{Na}^{+}(\mathrm{g} / \mathrm{L})$ & $7.28 \pm 0.6$ & $7.0 \pm 0.14$ & $7.0 \pm 0.3$ & 3.84 \\
$\mathrm{EC}(\mathrm{mS} / \mathrm{cm})$ & $33.6 \pm 2.1$ & $32.5 \pm 1.2$ & $31.1 \pm 1.7$ & 7.44 \\
$\mathrm{TDS}(\mathrm{g} / \mathrm{L})$ & $16.9 \pm 0.6$ & $15.7 \pm 0.8$ & $14.62 \pm 1.2$ & 13.49 \\
$\mathrm{TOC}(\mathrm{mg} / \mathrm{L})$ & - & $90.12 \pm 0.90$ & $33.80 \pm 0.34$ & 62.50 \\
$\mathrm{pH}$ & $6.7 \pm 0.1$ & $6.55 \pm 0.2$ & $6.8 \pm 0.1$ & - \\
\hline
\end{tabular}

\subsection{Reverse Osmosis and Membrane Distillation Performance}

The RO membrane performance was assessed in terms of the permeate flux $\left(J_{p}\right)$, membrane cleaning efficiency, and salt removal efficiencies. The time evolution of the permeate flux of pre-treated wastewaters in selected operating conditions is illustrated in Figure 2. Experimental data are referred to the processing of $16.1 \mathrm{~kg}$ of pre-treated FGD wastewaters with a production of $10.1 \mathrm{~kg}$ of permeate (recovery of about $63 \%$ ). The initial permeate flux of $11 \mathrm{~kg} / \mathrm{m}^{2} \mathrm{~h}$ sharply decreased during the first $20 \mathrm{~min}$, then continued to reduce in time, reaching a pseudo-steady state value higher than $1 \mathrm{~kg} / \mathrm{m}^{2} \mathrm{~h}$ after $120 \mathrm{~min}$. The permeate flux decline can be due to different factors, like the increase of the osmotic pressure during continuous concentration of the feed solution, as well as to membrane fouling and concentration polarization phenomena [30]. In particular, concentration polarization leads to a higher solute concentration at the membrane surface, which may cause salts deposition and also high osmotic pressure at the membrane surface, which means a flux decline when RO is performed at constant pressure [31].

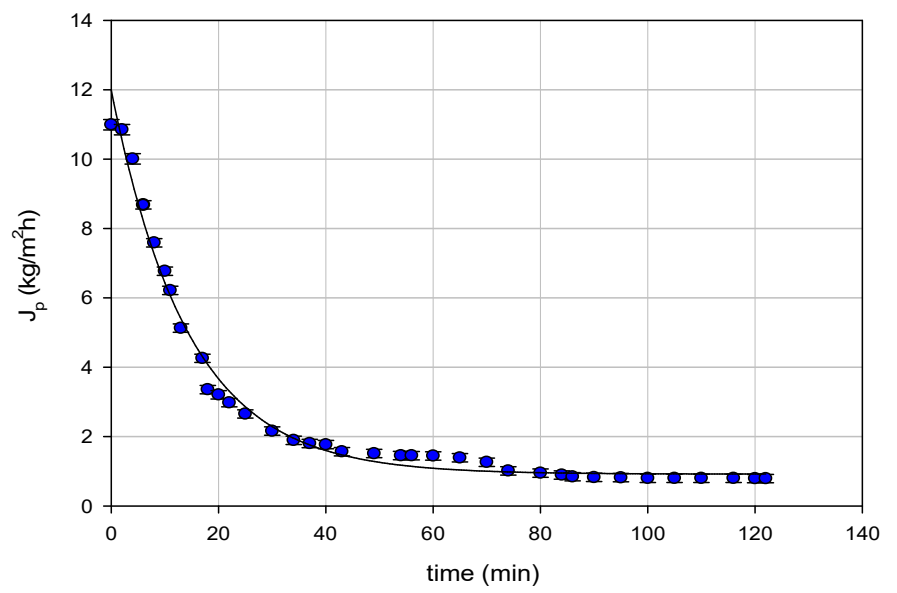

Figure 2. Reverse osmosis (RO) of pre-treated FGD wastewaters. Time course of permeate flux. $\left(\mathrm{TMP}=36\right.$ bar; $\left.\mathrm{T}=26.5^{\circ} \mathrm{C} ; \mathrm{Q}_{\mathrm{f}}=204 \mathrm{~L} / \mathrm{h}\right)$.

Figure 3 shows the hydraulic permeability of the RO membrane before and after the treatment of the UF permeate and after cleaning procedures: The initial hydraulic permeability $\left(W_{p 0}\right)$ of about $1.73 \mathrm{~kg} / \mathrm{m}^{2} \mathrm{hbar}$ was reduced to $0.81 \mathrm{~kg} / \mathrm{m}^{2} \mathrm{hbar}$ after the treatment of the UF permeate. According to 
these data, the fouling index was about 53.1\%. A first cleaning with distilled water at $30{ }^{\circ} \mathrm{C}$ recovered about $86 \%$ of the initial permeability $\left(W_{p 2}=1.49 \mathrm{~kg} / \mathrm{m}^{2} \mathrm{hbar}\right)$; a higher water flux recovery (of about $96 \%$ ) was reached through the chemical cleaning with acid detergent $\left(W_{p 3}=1.49 \mathrm{~kg} / \mathrm{m}^{2} \mathrm{hbar}\right.$ ). Therefore, experimental data confirmed that acid solutions are effective in removing membrane scaling of RO membranes [32].

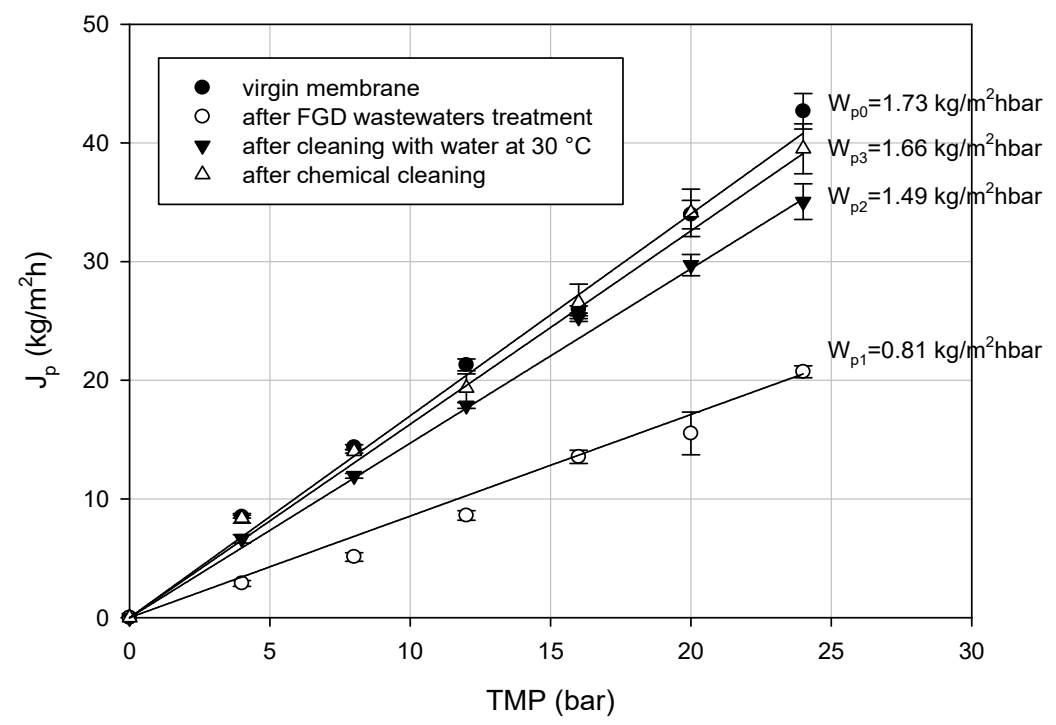

Figure 3. Permeate flux variation with TMP for the RO membrane before and after cleaning procedures $\left(W_{p 0}\right.$ initial hydraulic permeability; $W_{p 1}$ hydraulic permeability after RO treatment; $W_{p 2}$ hydraulic permeability after cleaning with water; $W_{p 3}$ hydraulic permeability after cleaning with acid detergent).

The RO retentate was further concentrated by DCMD. The trend of the transmembrane flux $\left(J_{w}\right)$ as a function of the MD recovery factor is reported in Figure 4. Experimental results indicated that the MD flux was not significantly affected by the recovery factor despite the growing feed concentration. The measured average flux was about $11 \mathrm{~kg} / \mathrm{m}^{2} \mathrm{~h}$. Additionally, the MD water recovery factor was also excellent and equal to $89.7 \%$. Moreover, the quite constant trend of the trans-membrane flux indicated that no significant fouling occurred in the MD test. This was confirmed by the value of $\mathrm{FI}_{\mathrm{MD}}(1.76 \%)$ determined via Equation (3).

These results were in agreement with those reported by Jia and Wang [25] in the treatment of FGD wastewaters by NF and MD. In their approach, the authors employed chemical softening and NF as pretreatment followed by VMD. The membrane flux of the VMD process remained stable during the whole continuous concentration and was of the order of $8.5 \mathrm{~L} / \mathrm{m}^{2} \mathrm{~h}$. On the other hand, the flux of a direct VMD process, which employed only MF as pretreatment, decreased sharply in the first $6 \mathrm{~h}$ due to the formation of $\mathrm{CaSO}_{4}$.

The chemical composition of the different samples coming from the RO/MD integrated process is summarized in Table 5. The EC of FGD wastewaters in the RO permeate was lowered down to $5.08 \pm 0.10 \mathrm{mS} / \mathrm{cm}$, with a removal efficiency of $85.4 \%$. 


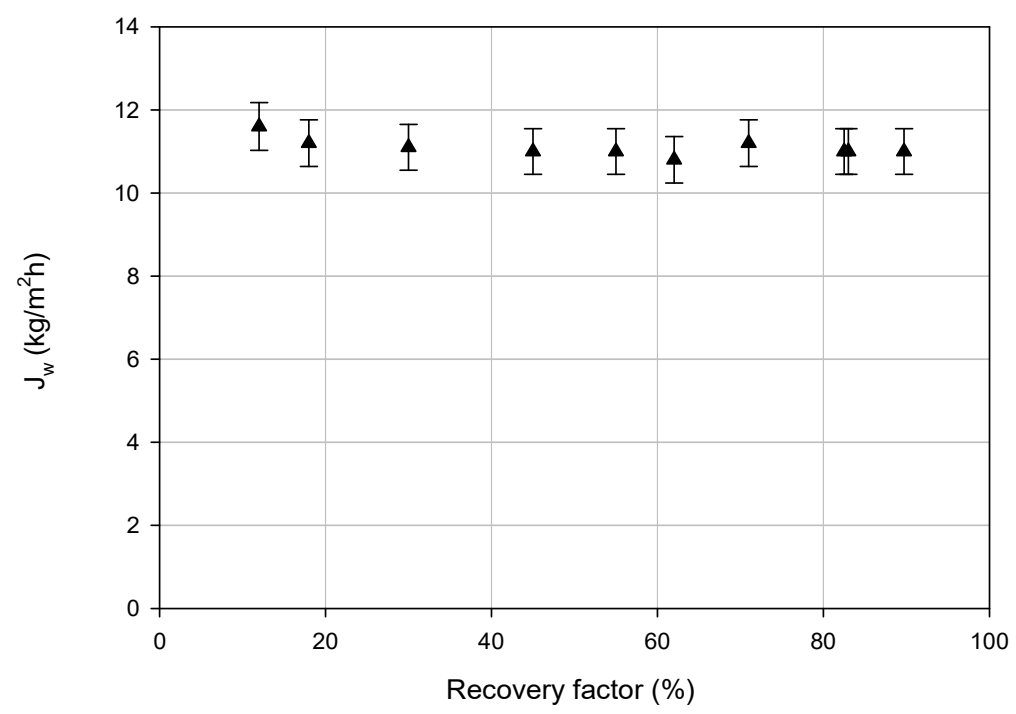

Figure 4. MD trans-membrane flux vs recovery factor.

Table 5. Chemical composition of FGD wastewaters coming from RO/MD treatments.

\begin{tabular}{ccccccc}
\hline Sample & $\begin{array}{c}\mathbf{C a}^{2+} \\
(\mathbf{p p m})\end{array}$ & $\begin{array}{c}\mathbf{M g}^{2+} \\
(\mathbf{p p m})\end{array}$ & $\begin{array}{c}\mathbf{N a}^{+} \\
(\mathbf{g} / \mathbf{L})\end{array}$ & $\begin{array}{c}\mathbf{E C} \\
(\mathbf{m S} / \mathbf{c m})\end{array}$ & $\begin{array}{c}\text { TDS } \\
(\mathbf{g} / \mathbf{L})\end{array}$ & $\mathbf{p H}$ \\
\hline Feed RO & $40.1 \pm 0.8$ & $67.4 \pm 1.3$ & $6.9 \pm 0.1$ & $34.7 \pm 0.7$ & $17.4 \pm 0.9$ & $7.53 \pm 0.4$ \\
Permeate RO & $6.9 \pm 0.4$ & n.d. & $0.70 \pm 0.01$ & $5.08 \pm 0.10$ & $2.53 \pm 0.10$ & $7.12 \pm 0.14$ \\
Retentate RO & $92.7 \pm 1.8$ & $175.1 \pm 3.5$ & $15.9 \pm 0.3$ & $69.4 \pm 1.4$ & $35.8 \pm 0.7$ & $7.78 \pm 0.15$ \\
Permeate MD & $16.22 \pm 0.32$ & n.d. & n.d. & $0.080 \pm 0.001$ & $0.040 \pm 0.001$ & $6.37 \pm 0.13$ \\
Retentate MD & $286.64 \pm 5.37$ & $539.8 \pm 10.8$ & $4.9 \pm 0.1$ & $158.3 \pm 3.1$ & $78.8 \pm 1.6$ & $8.15 \pm 0.16$ \\
\hline \multicolumn{7}{c}{ n.d. not detectable. }
\end{tabular}

TDS, $\mathrm{Ca}^{2+}$, and $\mathrm{Na}^{+}$ion concentrations in the $\mathrm{RO}$ permeate strongly reduced when compared with the feed solution. The observed rejection of the $\mathrm{RO}$ membrane towards $\mathrm{Na}^{+}$was of about $90 \%$, whereas, for $\mathrm{Ca}^{2+}$, TDS, and EC, rejections were higher than $83 \% . \mathrm{Mg}^{2+}$ ions were completely removed by the RO membrane, with a removal efficiency of 100\% (Figure 5).

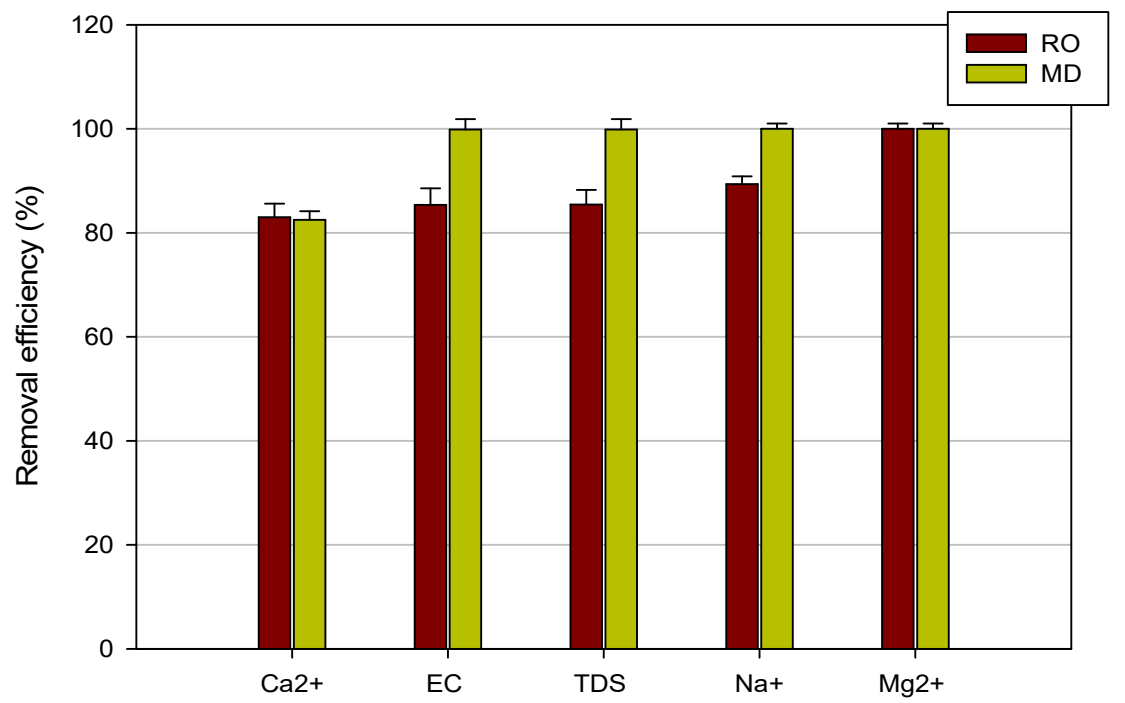

Figure 5. Removal efficiency of $\mathrm{RO}$ and MD membranes towards analyzed compounds.

The MD step removed both $\mathrm{Mg}^{2+}$ and $\mathrm{Na}^{+}$ions from the $\mathrm{RO}$ retentate (Figure 5). TDS and EC rejections were also very high and equal to $99.9 \%$. A lower retention value was measured for $\mathrm{Ca}^{2+}$ 
ions (about $82.5 \%$ ). This lower rejection could be attributed to calcium scaling on the membrane, which, however, did not affect the transmembrane flux (see Figure 4).

According to the experimental results, the combination of $\mathrm{RO}$ and $\mathrm{MD}$ processes reached a total recovery factor of about $94 \%$ and an MD permeate with a quality standard suitable to be reused in the power plant (needed purity: $\mathrm{EC}<800 \mu \mathrm{S} / \mathrm{cm}$ ), with a consequent saving in fresh water consumption and reduction of the volume of FGD wastewater to be disposed.

\section{Conclusions}

In the last decade, various flue gas desulfurization (FGD) technologies have been developed for removing sulfur dioxide from flue gases coming from fossil fuel thermoelectric power plants. FGD processes give origin to high salinity streams with a complex composition and the efficient treatment of FGD wastewater is one of the biggest challenges today.

In the present work, the problems of reducing water demand in power plants and of minimizing FGD wastewater discharge were dealt with. For this purpose, the potential of an integrated membrane-based process for FGD wastewater treatment and reuse was evaluated. In particular, the lab scale plant included: (1) A pre-treatment (chemical softening and UF) for reducing $\mathrm{Ca}^{+2}, \mathrm{Mg}^{2+}$, and TOC concentration in the raw wastewater, (2) an RO unit for the separation of salts from water, and (3) a MD unit for the treatment of $\mathrm{RO}$ retentate to extract more water, thus increasing the total water recovery factor of the process.

The experimental results indicated that high quality $\mathrm{RO}$ and MD permeate streams were obtained. In particular, the integrated $\mathrm{RO} / \mathrm{MD}$ process achieved a total recovery factor of about $94 \%$ and an $\mathrm{MD}$ permeate stream with an electrical conductivity of $80 \mu \mathrm{S} / \mathrm{cm}$ that makes it suitable to be reused in the power plant. This will imply significant benefits in terms of a reduction of water demand in the plant, minimization of wastewater to be discharged in the environment, and overall improvement in the sustainability of the process.

Author Contributions: E.D. supervised the technical activities and the paper writing. Alfredo Cassano, Alessandra Criscuoli and F.M. conceived and designed the experiments (softening and membrane treatment of FGD wastewaters). Lab scale experiments were performed by C.C. and A.A. P.A. and C.C. were involved in the analytical characterization of raw and pretreated feed, permeate and retentate samples. All Authors contributed to the interpretation and discussion of experimental results.

Funding: This work was performed within the Project "Materials Technologies for performance improvement of Cooling Systems in Power Plants" (MATChING) which received funding from the European Union's Horizon 2020 research and innovation program under the grant agreement number 686031.

Conflicts of Interest: The authors declare no conflict of interest.

\section{References}

1. Cheremisinoff, N.P. Pollution Control Handbook for Oil and Gas Engineering; Scrivener Publishing LLC: Salem, MA, USA, 2016; pp. 503-511.

2. Chu, P. Technical Manual: Guidance for Assessing Wastewater Impacts of FGD Scrubbers; EPRI Report\#1013313; Electric Power Research Institute: Palo Alto, CA, USA, 2006.

3. USEPA. Steam Electric Power Generating Point Source Category: Final Detailed Study Report; EPA 821-R-09-008; USEPA: Washington, DC, USA, 2009. Available online: https:/ /www.epa.gov/sites/production/files/201506/documents/steam-electric_detailed_study_report_2009.pdf (accessed on 26 November 2018).

4. Mcvaugh, J.; Wall, W.T. Optimization of heavy metals wastewater treatment effluent quality versus sludge treatment. In Proceedings of the 31st Industrial Waste Conference, Purdue University, Lafayette, IN, USA, 22-26 March 1976; pp. 17-25.

5. Blowes, D.W.; Ptacek, C.J.; Benner, S.G.; McRae, C.W.T.; Bennett, T.A.; Puls, R.W. Treatment of inorganic contaminants using permeable reactive barriers. J. Contam. Hydrol. 2000, 45, 123-137. [CrossRef]

6. Morrison, S.J.; Metzler, D.R.; Dwyer, B.P. Removal of As, Mn, Mo, Se, U, V and Zn from groundwater by zero-valent iron in a passive treatment cell: Reaction progress modeling. J. Contam. Hydrol. 2002, 56, 99-116. [CrossRef] 
7. Huang, Y.H.; Zhang, T.C.; Shea, P.J.; Comfort, S.D. Effects of oxide coating and selected cations on nitrate reduction by iron metal. J. Environ. Qual. 2003, 32, 1306-1315. [CrossRef] [PubMed]

8. Wilkin, R.T.; McNeil, M.S. Laboratory evaluation of zero-valent iron to treat water impacted by acid mine drainage. Chemosphere 2003, 53, 715-725. [CrossRef]

9. Shokes, T.E.; Moller, G. Removal of dissolved heavy metals from acid rock drainage using iron metal. Environ. Sci. Technol. 1999, 33, 282-287. [CrossRef]

10. EPRI. Selenium Removal by Iron Cementation from a Coal-Fired Power Plant Flue-Gas Desulfurization Wastewater in a Continuous Flow System-A Pilot Study; EPRI Report\#1017956; Electric Power Research Institute: Palo Alto, CA, USA, 2009.

11. NAMC. Review of Available Technologies for the Removal of Selenium from Water; Technical Report; North America Metals Council: Washington, DC, USA, 2010; Available online: http:/ /www.namc.org/docs/00062756.PDF (accessed on 10 July 2018).

12. Huang, Y.H.; Peddi, P.K.; Tang, C.; Zeng, H.; Teng, X. Hybrid zero-valent iron process for removing heavy metals and nitrate from flue-gas-desulfurization wastewater. Sep. Purif. Technol. 2013, 118, 690-698. [CrossRef]

13. Scherer, M.M.; Richter, S.; Valentine, R.L.; Alvarez, P.J. Chemistry and microbiology of permeable reactive barriers for in situ groundwater cleanup. Crit. Rev. Environ. Sci. Technol. 2000, 30, 363-411. [CrossRef]

14. Enoch, G.D.; Van Den Broeke, W.F.; Spiering, W. Removal of heavy metals and suspended solids from wastewater from wet lime (stone)-gypson flue gas desulphurization plants by means of hydrophobic and hydrophilic crossflow microfiltration membranes. J. Membr. Sci. 1994, 87, 191-198. [CrossRef]

15. Liu, C.; Farooq, K.; Doll, B.; Venkatadri, R. Economical and reliable mercury reduction in refinery and power plant discharge wastewater with robust microfiltration membrane technology. Desalin. Water Treat. 2013, 51, 4980-4986. [CrossRef]

16. Yin, N.; Liu, F.; Zhong, Z.; Xing, W. Integrated membrane process for the treatment of desulfurization wastewater. Ind. Eng. Chem. Res. 2010, 49, 3337-3341. [CrossRef]

17. Fritzmann, C.; Lowenberg, J.; Wintgens, T.; Melin, T. State-of-the-art of reverse osmosis desalination. Desalination 2007, 216, 1-76. [CrossRef]

18. Liu, H.Y.; Wang, J.L. Treatment of radioactive wastewater using direct contact membrane distillation. J. Hazard. Mater. 2013, 261, 307-315. [CrossRef] [PubMed]

19. Kezia, K.; Lee, J.; Weeks, M.; Kentish, S. Direct contact membrane distillation for the concentration of saline dairy effluent. Water Res. 2015, 81, 167-177. [CrossRef] [PubMed]

20. Macedonio, F.; Ali, A.; Poerio, T.; El-Sayed, E.; Drioli, E.; Abdel-Jawad, M. Direct contact membrane distillation for treatment of oilfield produced water. Sep. Purif. Technol. 2014, 126, 69-81. [CrossRef]

21. Quist-Jensen, C.A.; Macedonio, F.; Horbez, D.; Drioli, E. Reclamation of sodium sulfate from industrial wastewater by using membrane distillation and membrane crystallization. Desalination 2017, 401, 112-119. [CrossRef]

22. Chafidz, A.; Kerme, E.D.; Wazeer, I.; Khalid, Y.; Ajbar, A.; Al-Zahrani, S.M. Design and fabrication of a portable and hybrid solar-powered membrane distillation system. J. Clean. Prod. 2016, 133, 631-647. [CrossRef]

23. Eykens, L.; Hitsov, I.; De Sitter, K.; Dotremont, C.; Pinoy, L.; Nopens, I.; Van Der Bruggen, B. Influence of membrane thickness and process conditions on direct contact membrane distillation at different salinities. J. Membr. Sci. 2016, 498, 353-364. [CrossRef]

24. Koschikowski, J.; Wieghaus, M.; Rommel, M. Solar thermal-driven desalination plants based on membrane distillation. Desalination 2003, 156, 295-304. [CrossRef]

25. Jia, D.; Wang, J. Treatment of flue gas desulfurization wastewater with near-zero liquid discharge by nanofiltration-membrane distillation process. Sep. Sci. Technol. 2018, 53, 146-153. [CrossRef]

26. Conidi, C.; Macedonio, F.; Argurio, P.; Cassano, A.; Drioli, E. Performance of reverse osmosis membranes in the treatment of flue-gas desulfurization (FGD) wastewaters. Environments 2018, 5, 71. [CrossRef]

27. Li, Q.; Song, J.; Yu, H.; Li, Z.K.; Pan, X.H.; Yang, B. Investigating the microstructures and surface features of seawater RO membranes and the dependencies of fouling resistance performances. Desalination 2014, 352, 109-117. [CrossRef]

28. Lee, S.; Lee, E.; Elimelech, M.; Hong, S. Membrane characterization by dynamic hysteresis: Measurements, mechanisms, and implications for membrane fouling. J. Membr. Sci. 2011, 366, 17-24. [CrossRef] 
29. Ali, A.; Criscuoli, A.; Macedonio, F.; Argurio, P.; Figoli, A.; Drioli, E. Direct contact membrane distillation for treatment of wastewater for cooling tower in power industry. H2 Open J. 2018, 1, 57-68. [CrossRef]

30. Sim, L.N.; Chong, T.H.; Taheri, A.H.; Sim, S.T.V.; Lai, L.; Krantz, W.B.; Fane, A.G. A review of fouling indices and monitoring techniques for reverse osmosis. Desalination 2018, 434, 169-188. [CrossRef]

31. Shirazi, S.; Lin, C.J.; Chen, D. Inorganic fouling of pressure-driven membrane processes-A critical review. Desalination 2010, 250, 236-248. [CrossRef]

32. Filloux, E.; Wang, J.; Pidou, M.; Gernjak, W.; Yuan, Z. Biofouling and scaling control of reverse osmosis membrane using one-step cleaning-potential of acidified nitrite solution as an agent. J. Membr. Sci. 2015, 495, 276-283. [CrossRef]

(C) 2018 by the authors. Licensee MDPI, Basel, Switzerland. This article is an open access article distributed under the terms and conditions of the Creative Commons Attribution (CC BY) license (http:// creativecommons.org/licenses/by/4.0/). 